\title{
Pembebasan Bersyarat Bagi Narapidana Terorisme
}

\author{
Conditional Release For Prisoners of Terrorism
}

\author{
Rusnadi Dwi Saputra \\ Kantor Wilayah Kementrian Hukum Dan Hak Asasi Manusia Upt. Bapas Kelas II A Kendari \\ E-mail: rusnadidwisaputra07@gmail.com
}

Herman

Pascasarjana Universitas Halu Oleo

E-mail:man.herman76@yahoo.com

Oheo K. Haris

Pascarjana Universitas Halu Oleo

E-Mail: oheokh@gmail.com

\begin{abstract}
Granting the Conditional Release to the Prisoners of Terrorism Criminal Acts in the Perspective of Prisoners' Rights and Legis Ratio Against Restrictions of parole Granting to the Criminal Prisoners for Terrorism Criminal Principles. constitutes human rights which then these rights are set forth in a legal product regulated in Law No. 39 of 1999 concerning human rights in which it is stated that one of the rights for terrorist prisoners is to obtain parole. Fulfillment of the rights of prisoners of terrorism offenders to obtain parole, in accordance with the concept of restorative justice or restorative justice that establishes the restoration of the right to perpetrators of criminal acts of terrorism. While the Legis Rationing of Conditional Granting Prisoners to Terrorism is based on the principle of granting rights and responsibilities of the government that parole is intended as the last remaining criminal in order to return the convicted to the good of the community. Related to terrorism crimes, the process of criminal punishment against perpetrators to maintain the stability of the country's security. In addition, the de-radicalization program is an attempt by the government to reduce radical activities and neutralize radical ideology for the people involved in terrorism crime. This program is carried out as an effort in parole for prisoners of terrorism.
\end{abstract}

Keyword: Legis Ratio; Prisoners; Parole; Terrorism

Abstrak: Pemberian Pembebasan Bersyarat Terhadap Narapidana Pelaku Tindak Pidana Terorisme Dalam Perspektif Hak-hak Narapidana serta ratio legis Terhadap Pembatasan Pemberian Pembebasan Bersyarat terhadap Narapidana Tindak Pidana Terorisme. Dalam tesis penulis memfokuskan Pembebasan Bersyarat Terhadap Narapidana Pelaku Tindak Pidana Terorisme Dalam Perspektif Hak-hak Narapidana bahwa Pembebasan bersyarat merupakan hak asasi manusia yang kemudian hak asasi tersebut dituangkan dalam produk hukum yang diatur dalam Undang-Undang No. 39 tahun 1999 tentang hak asasi manusia dimana dinyatakan bahwa salah satu Hak bagi narapidana teroris adalah 
memperoleh pembebasan bersyarat. Pemenuhan hak narapidana pelaku tindak pidana terorisme untuk memperoleh pembebasan bersyarat, sesuai dengan konsep keadilan restoratif atau restorative justice yang mengedepankan adanya pemulihan hak terhadap pelaku tindak pidana terorisme. Sedangkan Ratio Legis Pemberian Bersyarat Bagi Narapidana Terorisme, didasarkan pada prinsip pemberian hak dan tanggung jawab pemerintah bahwa Pembebasan bersyarat tersebut dimaksudkan sebagai sisa pidana terakhir dalam rangka pengembalian terpidana dengan baik ke masyarakat. Terkait dengan kejahatan terorisme maka proses pemidanaan terhadap pelaku untuk menjaga stabilitas keamanan negara. Selain itu, Program deradikalisasi sebagai upaya pemerintah untuk mereduksi kegiatan radikal dan menetralisasi paham radikal bagi masyarakatyang terlibat tindak pidana terorisme program ini dilakukan sebagai upaya dalam pembebasan bersyarat bagi narapidana terorisme.

Kata kunci: Ratio Legis; Narapidana; Pembebasan Bersyarat; Terorisme

\section{PENDAHULUAN}

Bertolak dari pandangan tentang hukum sebagai pengayoman. Hal ini membuka jalan perlakuan terhadap narapidana dengan cara pemasyarakatan sebagai tujuan pidana penjara. ${ }^{1}$ Konsep pemasyarakatan tersebut kemudian disempurnakan oleh Keputusan Konferensi Dinas Para pimpinan Kepenjaraan pada tanggal 27 April 1964 yang memutuskan bahwa pelaksanaan pidana penjara di Indonesia dilakukan dengan sistem pemasyarakatan, suatu pernyataan di samping sebagai arah tujuan, pidana penjara dapat juga menjadi cara untuk membimbing dan membina.

Pidana penjara atau pemasyarakatan merupakan salah satu bagian dari hukuman yang dapat dijatuhkan kepada seorang terpidana yang telah divonis dengan putusan pengadilan yang telah memiliki kekuatan hukum yang tetap (inkrah). Fungsi pemidanaan pada saat ini tidak lagi sekedar pemenjaraan, tetapi pemidanaan dimaksudkan sebagai tempat atau sarana pembinaan, rehabilitasi dan reintegrasi warga binaan lembaga pemasyarakatan. ${ }^{2}$

Pelaksanaan pembinaan pemasyarakatan didasarkan atas prinsip-prinsip sistem pemasyarakatan untuk merawat, membina, mendidik, dan membimbing narapidana dengan tujuan agar menjadi warga yang baik dan berguna. Pembinaan yang terbaik bagi keberhasilan narapidana dalam menjalani pidana dan dapat kembali ke masyarakat serta tidak mengulangi lagi perbuatannya adalah pembinaan yang berasal dari dalam diri narapidana itu sendiri. Namun yang terlebih penting adalah, perlunya penghayatan asas proporsionalitas dalam

Dwidja Priyatno, Sistem Pelaksanaan Pidana Penjara di Indonesia, Bandung: Refika Aditama, 2006, hlm. 97.

Samosir Djisman, Fungsi Pidana Penjara Dalam Sistem Pemidanaan di Indonesia, Bandung: Bina Cipta, 2001, hlm. 4 . 
penjatuhan pidana, yakni proporsionalitas atas kepentingan masyarakat, kepentingan negara, kepentingan si pelaku tindak pidana dan kepentingan korban tindak pidana. ${ }^{3}$

Fungsi pemidanaan tersebut mengarahkan supaya narapidana tidak melakukan perbuatan pidana dan menyadarkan serta mengembalikan warga binaan pemasyarakatan tersebut ke dalam lingkungan masyarakat, menjadikan ia bertanggung jawab terhadap dirinya, keluarga dan masyarakat sekitar atau lingkungannya. ${ }^{4}$ Pemidanaan pada saat ini lebih ditujukan sebagai pemulihan konflik atau menyatukan terpidana dengan masyarakat. ${ }^{5}$

Undang-Undang Nomor 12 Tahun 1995 tentang Pemasyarakatan, dalam penjelasan umumnya memuat pernyataan bahwa tujuan pemidanaan adalah upaya untuk menyadarkan narapidana dan anak pidana untuk menyesali perbuatannya, dan mengembalikannya menjadi warga masyarakat yang baik, taat kepada hukum, menjunjung tinggi nilai-nilai moral, sosial dan keagamaan, sehingga tercapai kehidupan masyarakat yang aman, tertib dan damai.

Pembebasan bersyarat kepada narapidana agar narapidana dapat langsung menyesuaikan dirinya dengan kehidupan masyarakat sebelum mengakhiri masa pidananya. Keputusan untuk memberikan pembebasan bersyarat dikeluarkan oleh Menteri Kehakiman setelah mendengar pendapat Penuntut Umum dan Pejabat LAPAS (lembaga pemasyarakatan) yang lebih mengetahui tingkah laku terpidana selama menjalani pidana penjara. Wewenang pemberian pembebasan bersyarat ada pada Menteri Hukum dan Hak Asasi Manusia dengan berbagai syarat administratif yang harus dipenuhi oleh narapidana.

Terkait dengan fenomena kejahatan terorisme, maka proses pemidanaan terhadap pelaku tindak pidana terorisme merupakan kajian kebijakan dalam menjaga stabilitas Negara. Hal ini menjadikan lembaga pemasyarakatan sebagai tempat yang memiliki peranan dalam melakukan pembinaan terhadap pembinaan narapidana teroris untuk tidak mengulangi perbuatannya. Pemasyarakatan bagi narapidana teroris bertujuan untuk membina dan mendidik menjadi orang yang lebih baik. Perubahan paradigma tempat pemidanaan dari penjara menjadi lembaga pemasyarakatan sebagaimana yang diatur dalam Undang-Undang Nomor 12 Tahun 1995 tentang pemasyarakatan membawa konsekuensi yuridis berupa perubahan tujuan pemidanaan dari pembalasan menjadi pembinaan.

3 Oheo K. Haris, "Telaah Yuridis Penerapan Sanksi Pidana Di Bawah Minimum Khusus Pada Perkara Pidana Khusus”, Jurnal Ius Kostituendum, Volume 2 Issue 2, Oktober 2017, hlm. 241.

4 Ibid,

5 Peraturan Menteri Hukum dan Hak Asasi Manusia Nomor M.HH-OT.02.02 tahun 2009 Tentang Cetak Biru Pembaharuan Pelaksanaan Sistem Pemasyarakatan. 
Berbagai kebijakan telah dilakukan oleh pemerintah dalam penanggulangan tindak pidana terorisme baik berupa peraturan perundang-undangan maupun dalam berbagai kebijakan hukum pidana lainnya terkait tindak pidana terorisme. ${ }^{6}$ Salah satu kebijakan hukum pidana pada bidang terorisme dengan adanya lahirnya Undang-Undang Nomor 5 Tahun 2018 Tentang Perubahan atas Undang-Undang Nomor 15 Tahun 2003 Tentang Pemberantasan Tindak Pidana Terorisme.

Pemberian pembebasan bersyarat kepada narapidana yang melakukan tindak pidana terorisme mendapat pertentangan dari masyarakat luas. Pemberian pembebasan bersyarat ini seolah mematahkan usaha dan semangat bangsa ini untuk memberantas tindak pidana terorisme. Tentu sangat tidak adil apabila pelaku terorisme yang telah mengakibatkan banyak hilangnya nyawa dibebaskan dengan pemberian pembebasan bersyarat. Pembebasan bersyarat ini juga berpotensi untuk tidak memberikan efek jera pada terpidana terorisme karena pembebasan bersyarat ini dapat menjadi jalan keluar untuk lari dari tanggung jawab atas hilangnya nyawa akibat dari kejahatan yang telah dilakukan.

\section{METODE PENELITIAN}

Tipe penelitian yang digunakan yaitu penelitian hukum yang bersifat Normatif, yang merupakan suatu proses untuk menemukan aturan hukum, prinsip-prinsip hukum, maupun doktrindoktrin hukum guna menjawab isu hukum yang dihadapi yang menghasilkan argumentasi, teori dan konsep baru sebagai preskripsi dalam menyelesaikan masalah yang dihadapi. ${ }^{7}$

Sumber bahan hukum yang digunakan dalam penelitian dalam penulisan ini adalah bahan hukum primer, bahan hukum sekunder dan bahan non hukum.

\section{ANALISIS DAN PEMBAHASAN}

\section{Pembebasan Bersyarat Terhadap Narapidana Pelaku Tindak Pidana Terorisme Dalam Perspektif Hak-hak Narapidana}

Hak Narapidana adalah hak-hak yang dimiliki oleh narapidana. Di dalam Kamus Besar Bahasa Indonesia dijelaskan bahwa hak memiliki pengertian tentang sesuatu hal yang benar, milik, kepunyaan, kewenangan, kekuasaan untuk berbuat sesuatu (karena telah ditentukan oleh

\footnotetext{
6 Romli Atmasasmita, Analisis dan Evaluasi Peraturan Perundang-undangan tentang Pemberantasan Tindak Pidana Terorisme (Undang-Undang Nomor 15 tahun 2003), Jakarta: Badan Pembinaan Hukum Nasional Kementerian Hukum dan Hak Asasi Manusia, 2012, hlm. 73.

7 Peter Mahmud Marzuki, Penelitian Hukum, Jakarta: Kencana Group, 2005, hlm. 35.
} 
undang-undang, aturan, dsb.), kekuasaan yang benar atas sesuatu atau untuk menuntut sesuatu, derajat atau martabat. 8

Berdasarkan Pasal 1 ayat (7) Undang-Undang Nomor 12 Tahun 1995 Tentang Pemasyarakatan, narapidana adalah terpidana yang menjalani pidana hilang kemerdekaan di Lembaga Pemasyarakatan. Menurut Pasal 1 ayat (6) Undang-Undang Nomor 12 Tahun 1995 Tentang Pemasyarakatan, terpidana adalah seseorang yang dipidana berdasarkan putusan pengadilan yang telah memperoleh kekuatan hukum tetap. Dari pernyataan di atas, dapat disimpulkan bahwa narapidana adalah orang atau terpidana yang sedang menjalani masa hukumannya di Lembaga Pemasyarakatan dimana sebagian kemerdekaannya hilang. Hak-hak narapidana ini adalah hak-hak yang dimiliki oleh narapidana yang diatur dalam peraturan perundang-undangan.

Proses pemasyarakatan berdasarkan pada tahap pengamanan di Lembaga Pemasyarakatan salah satu yaitu Tahap integrasi, yaitu dimulai dari narapidana telah menjalani 2/3 masa pidananya sampai narapidana yang bersangkutan telah selesai masa pidananya. Apabila narapidana sudah menjalani 2/3 masa pidananya dan paling sedikit 9 bulan, dapat diusulkan untuk diberikan pembebasan bersyarat (PB). Artinya bahwa pada tahapan ini seorang narapidana akan diberikan haknya untuk mendapatkan pembebasan bersyarat manakala narapidana benar-benar mengikuti aturan-aturan yang ada di Lembaga Pemasyarakatan serta mengikuti pembinaan yang diberikan oleh petugas-petugas pemasyarakatan dengan tekun hingga berkelakuan baik dan tidak pernah mendapatkan hukuman disiplin.

Penempatan narapidana sebagai subjek pembinaan merupakan cerminan dari hak narapidana yang dilindungi oleh negara. Pembinaan ini dilakukan melalui sebuah sistem yang kini dikenal dengan istilah sistem pemasyarakatan. Dalam sistem pemasyarakatan, terpidana disebut dengan istilah warga binaan. Pembinaan yang dilakukan di lembaga pemasyarakatan merupakan sarana untuk mencegah agar warga binaan tidak mengulangi kembali perbuatannya selepas dari lembaga pemasyarakatan. Melalui program-program pembinaan, warga binaan diharapkan dapat kembali diterima oleh lingkungan sosialnya.

Sistem Pemasyarakatan pada dasarnya merupakan buah pikiran untuk penerapan konsep "Treatment of offender" dan dapat dianggap menggantikan sistem kepenjaraan. ${ }^{9}$ Namun

8 A. Gunawan Setiardja, Hak-Hak Asasi Manusia Berdasarkan Ideologi Pancasila. Yogyakarta, Kanisius, 1993, hlm. 89-89

9 HR. Abdussalam, Sistem Peradilan Pidana, Jakarta: Restu Agung, 2007, hlm. 333. 
dalam implementasinya ternyata penerapan konsep pemasyarakatan tersebut belum efektif. Hal ini tampak dari masih terus terjadinya berbagai kasus yang bertentangan ataupun menghilangkan makna dari tujuan pemasyarakatan itu sendiri.

Hal ini terlihat dengan kondisi LAPAS (Lembaga Pemasyarakatan) yang sebagian besar dalam keadaan over kapasitas. Untuk mengatasi hal tersebut maka perlu diadakan perombakan dalam sistem pemidanaan. Penambahan alternatif pemidanaan lain di samping pidana penjara dapat mengatasi titik tolak dalam mengatasi over kapasitas sebagian besar LAPAS di Indonesia.

Langkah berikutnya adalah dengan mengefektifkan pemberian hak-hak narapidana yaitu pemberian Remisi, Cuti Mengunjungi Keluarga, Cuti Menjelang Bebas, Pembebasan Bersyarat dan hak-hak lain sesuai dengan peraturan perundang-undangan yang berlaku. Tetapi langkah pemberian hak-hak narapidana sebagaimana dimaksud perlu dilakukan pengecualian melalui pengetatan khususnya terhadap narapidana yang melakukan tindak pidana extra ordinary crime. Jenis tindak pidana extra ordinary crime khususnya adalah tindak pidana Terorisme. Karena Tindak kejahatan terorisme merupakan kejahatan terhadap kemanusiaan dan peradaban serta merupakan salah satu ancaman serius terhadap kedaulatan setiap negara karena terorisme sudah merupakan kejahatan yang bersifat internasional yang menimbulkan bahaya terhadap keamanan, perdamaian dunia serta merugikan kesejahteraan masyarakat sehingga perlu dilakukan pemberantasan secara berencana dan berkesinambungan sehingga hak asasi orang banyak dapat dilindungi dan dijunjung tinggi. 10

Analisis penulis berdasarkan teori di atas, bahwa Pembebasan bersyarat merupakan hak asasi manusia yang kemudian hak asasi tersebut dituangkan dalam produk hukum yang di atur dalam Undang-Undang No. 39 tahun 1999 tentang hak asasi manusia. Seiring dengan perubahan penjara menjadi lembaga pemasyarakatan, penekanan perlakuan terhadap narapidana dan anak pidana seharusnya telah berubah secara total, karena dasar pijakannya sudah berubah dari pembalasan menjadi pembinaan. Oleh karena perubahan itu, kepada narapidana dan anak pidana telah diberikan berbagai macam hak, seperti hak untuk melakukan ibadah, mendapat perawatan (rohani dan jasmani), pendidikan dan pengajaran, pelayanan kesehatan dan makanan yang layak, menyampaikan keluhan, menerima kunjungan keluarga, penasihat hukum, atau orang tertentu lainnya, pengurangan masa pidana (remisi), berasimilasi (termasuk cuti mengunjungi keluarga), pembebasan bersyarat, dan cuti menjelang bebas. Hakhak tersebut diberikan seiring dengan proses pembinaan atau pemasyarakatan yang telah

10 Romli Asmasasmita, Kapita Selekta Kejahatan Bisnis dan Hukum Pidana, Buku 2, Jakarta: Fikahati Aneska, 2013, hlm. 101. 
dilakukan oleh lembaga pemasyarakatan Pembinaan dalam sistem pemasyarakatan dilaksanakan berdasarkan asas pengayoman, persamaan perlakuan dan pelayanan, pendidikan, pembimbingan, penghormatan harkat dan martabat manusia, kehilangan kemerdekaan merupakan satu-satunya penderitaan, dan terjaminnya hak untuk tetap berhubungan dengan keluarga dan orang-orang tertentu. Sistem pemasyarakatan telah dirancang sedemikian rupa sehingga sesuai dengan konsep pencetus lembaga pemasyarakatan itu sendiri, yaitu Sahardjo bahwa kehilangan kemerdekaan (kebebasan) merupakan satu-satunya penderitaan yang dialami narapidana dan anak pidana, sedangkan hak-hak lain tidak boleh dikurangi.

Perlindungan dan pemenuhan hak asasi manusia bukan hanya diberikan di masyarakat tetapi di berikan dan diterapkan terhadap narapidana di lembaga Pemasyarakatan (Lapas) dan Rumah Tahanan Negara (Rutan). Perlindungan dan pemenuhan hak asasi manusia di lembaga pemasyarakatan merupakan peran yang sangat strategis dalam merealisasikan tujuan akhir dari sistem peradilan pidana yaitu pembinaan dan pengembalian rasa keadilan yang berdasarkan atas Pancasila, UUD 1945 yakni keadilan yang berperikemanusiaan yang berlandaskan hak asasi manusia kepada pelanggar hukum, bahkan sampai pada penanggulangan kejahatan.

Hak asasi manusia (HAM) adalah hak atau kewenangan yang melekat pada diri individu sejak ia lahir secara kodrati yang tidak dapat dirampas atau dicabut keberadaannya. HAM ada selama adanya manusia, sejak dahulu sampai sekarang. HAM tidak dapat berubah kedudukannya. Kedaulatan suatu negara akan berwibawa dan bermartabat apabila terdapat penghargaan yang berarti terhadap HAM dari seluruh elemen masyarakat dan pemerintahnya. ${ }^{11}$

Sebagai negara hukum hak-hak narapidana itu dilindungi dan diakui oleh penegak hukum, khususnya pada Lembaga Pemasyarakatan. Narapidana juga harus diayomi hakhaknya walaupun telah melanggar hukum. Di samping itu juga ada ketidakadilan perilaku bagi narapidana, misalnya penyiksaan, tidak mendapat fasilitas yang wajar dan tidak adanya kesempatan untuk mendapat Pembebasan bersyarat.

Pembebasan bersyarat merupakan salah satu hak narapidana yang menjadi bagian dari program pembinaan dalam sistem pemasyarakatan, dimana program ini memberikan kesempatan kepada narapidana untuk berintegrasi dengan masyarakatnya lebih cepat. Program ini menjadi alternatiflegal yang dapat membantu Direktorat Jenderal Pemasyarakatan

11 Jimly Asshiddiqie, Konstitusi dan Hak Asasi Manusia, Jakarta: Konstitusi Press, 2005, hlm. 53. 
dalam mengurangi masalah kelebihan kapasitas yang terjadi hampir di seluruh Lapas/Rutan di Indonesia.

Pada prinsipnya pembebasan bersyarat diberikan kepada semua tindak pidana, baik umum maupun yang khusus. Hanya ada syarat-syarat umum ada juga syarat khususnya. Syaratsyarat umum diberikan kepada orang-orang (Narapidana) yang tindak pidana umum, fase-fase yang telah di lalui misalnya masuk pada fase Middle Security kemudian Narapidana tersebut di lengkapi administrasinya maka diberikanlah atau diusulkannya pembebasan bersyarat, untuk pidana khusus seperti tipikor, kejahatan trafficking, teroris dan narkoba yang perlakuannya berbeda dengan umum.

Melalui Peraturan Pemerintah No. 99 tahun 2012 tentang Perubahan Kedua Atas Peraturan Pemerintah Nomor 32 Tahun 1999 tentang Syarat dan Tata Cara Pelaksanaan Hak Warga Binaan Pemasyarakatan. Ditegaskan bahwa pemberian Remisi, Asimilasi, dan Pembebasan Bersyarat bagi pelaku tindak pidana terorisme, narkotika dan prekursor narkotika, psikotropika, korupsi, kejahatan terhadap keamanan negara dan kejahatan hak asasi manusia yang berat, serta kejahatan transnasional terorganisasi lainnya perlu diperketat syarat dan tata caranya untuk memenuhi rasa keadilan masyarakat. Tindak pidana terorisme, narkotika dan prekursor narkotika, psikotropika, korupsi, kejahatan terhadap keamanan negara dan kejahatan hak asasi manusia yang berat, serta kejahatan transnasional terorganisasi lainnya merupakan kejahatan luar biasa karena mengakibatkan kerugian yang besar bagi negara atau masyarakat atau korban yang banyak atau menimbulkan kepanikan, kecemasan, atau ketakutan yang luar biasa kepada masyarakat.

Program Deradikalisasi merupakan semua upaya untuk mentransformasi dari keyakinan atau ideologi radikal menjadi tidak radikal dengan pendekatan multi dan interdisipliner (agama, sosial, budaya, dan selainnya) bagi orang yang terpengaruh oleh keyakinan radikal. Atas dasar itu, deradikalisasi lebih pada upaya melakukan perubahan kognitif atau memoderasi pemikiran atau keyakinan seseorang. 12

Tujuan umum deradikalisasi adalah untuk membuat para teroris atau kelompok yang melakukan kekerasan bersedia meninggalkan atau melepaskan diri mereka dari aksi dan kegiatan terorisme. Sedangkan Secara khusus, tujuan deradikalisasi adalah: ${ }^{13}$

1) Membuat para teroris mau meninggalkan aksi terorisme dan kekerasan.

12 Suhardi Alius, Pemahaman Membawa Bencana: Bunga Rampai Penanggulangan Terorisme, Jakarta: Gramedia Pustaka Utama, 2019, hlm. 76.

13 Saefudin Zuhri, Deradikalisasi Terorisme, Jakarta: Daulatpress, 2017, hlm. 103. 
2) Kelompok radikal mendukung pemikiran yang moderat dan toleran.

3) Kaum radikalis dan teroris dapat mendukung program-program nasional dalam membangun kehidupan berbangsa dan bernegara dalam bingkai Negara Kesatuan Republik Indonesia (NKRI).

Program Deradikalisasi merupakan suatu upaya mereduksi kegiatan-kegiatan radikal dan menetralisasi paham-paham radikal bagi mereka yang terlibat teroris dan simpatisannya serta anggota masyarakat yang terekspose paham-paham radikal teroris. Namun menurut analisis penulis bahwa Program deradikalisasi merupakan program yang gagal dalam menangani perkara tindak pidana terorisme, hal ini dapat di lihat program deradikalisasi tidak menyentuh ideologi pada objeknya. Program deradikalisasi yang di lakukan oleh pemerintah hanya dapat mengubah perilaku radikal dan tidak dapat menghilangkan ideologi radikal. Program deradikalisasi dinilai gagal dengan adanya serangan bom Surabaya Rentetan aksi teror menimbulkan pertanyaan mengenai efektivitas program deradikalisasi.

Lebih lanjut menurut penulis bahwa berdasarkan data pada tahun 2017 ada 400 eks anggota kelompok terorisme di Indonesia yang belum tersentuh program deradikalisasi, ${ }^{14}$ eks anggota kelompok terorisme tersebut menolak mengikuti program deradikalisasi hal ini dikarenakan dalam yang Undang-Undang Terorisme tidak diatur mengenai kewajiban terorisme dalam mengikuti program deradikalisasi. bahkan dalam aturan yang baru UU No. 5 Tahun 2018 Tentang Pemberantasan Tindak Pidana Terorisme tidak secara eksplisit memberikan kewajiban kepada narapidana teroris untuk mengikuti program deradikalisasi.

Menurut penulis bahwa program deradikalisasi sebagai upaya mereduksi kegiatan radikal dan menetralisasi paham radikal bagi masyarakat yang terlibat tindak pidana terorisme program ini dilakukan sebagai upaya dalam pembebasan bersyarat bagi narapidana terorisme, dalam pelaksanaan program deradikalisasi tidak memiliki tolak ukur mengenai tingkat keberhasilan sehingga tidak adanya pencapai serta kurang jelas mengenai subjek atau sasaran program deradikalisasi.

Sehingga menurut penulis perlunya eksistensi Kajian hukum dalam pelaksanaan program deradikalisasi hal ini dikarenakan kejahatan terorisme merupakan kejahatan luar biasa yang menimbulkan dampak negatif baik bagi negara maupun bagi masyarakat, peningkatan intensitas dapat berdampak pada disintegrasi sosial yang mengakibatkan

14 Heyder Affan, "Mengapa 400 eks napi terorisme tidak ikut program deradikalisasi?", BBC Indonesia, https://www.bbc.com/indonesia/indonesia-39177219, diakses pada tanggal 20 Agustus 2019. 
ketahanan masyarakat menjadi lemah dan rentan akan hasutan-hasutan negatif yang dapat memecah belah NKRI dan kehidupan berbangsa dan bernegara.

\section{Ratio Legis Terhadap Pembatasan Pemberian Pembebasan Bersyarat Terhadap Narapidana Pelaku Tindak Pidana Terorisme}

Pembebasan bersyarat merupakan proses pembinaan narapidana di luar Lembaga Pemasyarakatan setelah menjalani sekurang-kurangnya 2/3 (dua pertiga) masa pidananya dengan ketentuan 2/3 (dua per tiga) masa pidana tersebut minimal 9 (sembilan) bulan. 15 Pembebasan bersyarat tersebut merupakan bagian dari fungsi Lembaga Pemasyarakatan, yang merupakan salah satu dari bagian sistem peradilan pidana Indonesia, yaitu Kepolisian, Kejaksaan, dan Pengadilan. 16

Kitab Undang-Undang Hukum Pidana (KUHP) yang berlaku hingga sekarang, pelepasan bersyarat dapat diberikan kepada terpidana yang telah menjalani 2/3 (dua per tiga) dari lamanya pidana penjara yang dijatuhkan kepadanya, yang sekurang-kurangnya harus 9 (sembilan) bulan, dimana ketentuan ini juga berlaku pada saat istilah pembebasan bersyarat digunakan. Selanjutnya, dalam peraturan perundang-undangan yang mengatur mengenai pelepasan bersyarat, yaitu KUHP dan Ordonansi Pelepasan Bersyarat (Voorwaardelijke Invrijheidsteeling) S. 1917-749, tidak terdapat ketentuan mengenai bimbingan dan pembinaan terhadap terpidana yang menjalani pembebasan bersyarat. Hal tersebut berbeda pada saat istilah pembebasan bersyarat digunakan, yakni terdapat pengaturan mengenai bimbingan dan pembinaan dalam ketentuan pembebasan bersyarat, yaitu dalam Undang-Undang Nomor 12 Tahun 1995 tentang Pemasyarakatan, yang menyatakan bahwa terpidana yang menjalani pembebasan bersyarat wajib mengikuti bimbingan yang diberikan oleh Balai Pemasyarakatan (BAPAS). Dalam pasal 28I ayat (5) tersebut dijelaskan bahwa bentuk perlindungan serta kepastian hukum dalam pemenuhan hak asasi manusia akan dituangkan dalam peraturan perundang-undangan, artinya selain dalam Undang-Undang Dasar Republik Indonesia Tahun 1945 nantinya akan dibentuk peraturan perundang-undangan lainnya yang mengatur penegakan dan perlindungan hak asasi manusia. Saat ini telah ada undang-undang yang khusus mengatur mengenai hak asasi manusia itu sendiri yaitu Undang-Undang Republik Indonesia No. 39 Tahun 1999 tentang hak asasi manusia. Selain itu terdapat pula ratifikasi The International

15 Peraturan Pemerintah No. 99 Tahun 2012 tentang Syarat dan Tata Cara Pelaksanaan HakWarga Binaan Pemasyarakatan.

16 Petrus Irwan Pandjaitan, Wiwik Sri Widiarty, Pembaharuan pemikiran DR. Sahardjo Mengenai Pemasyarakatan Narapidana, Jakarta: Indhill Co, 2008, hlm. 23. 
Covenan on Civil and political Rights (1966) yang dituangkan dalam Undang-Undang Republik Indonesia No. 12 Tahun 2005 tentang pengesahan International Covenan on Civil and political Rights serta berbagai peraturan lain yang mengatur mengenai hak asasi manusia khususnya hak politik. ${ }^{17}$

Menurut penulis bahwa berdasarkan dari tujuan daripada penjatuhan pidana selain pembinaan kepada pelaku atas kejahatannya juga bermaksud mengamankan masyarakat, dari kedua tujuan tersebut juga bermaksud untuk mempersiapkan dan memberikan narapidana tersebut bekal saat dikembalikan ke dalam masyarakat. Pembinaan narapidana yang dilaksanakan berdasarkan sistem kemasyrakatan diharapkan mampu untuk mencapai tujuantujuan dari pemidanaan, untuk mewujudkan tujuan tersebut salah satu upayanya adalah dengan pemberian pembebasan bersyarat. Sehingga sangat tegas bahwa hukum pidana harus disepadankan dengan kebutuhan untuk melindungi dan mempertahankan kepentingankepentingan masyarakat. Maka sangat tepat bahwa pembaharuan hukum pidana harus dilakukan dengan pendekatan kebijakan, karena pada hakikatnya pembaharuan hukum merupakan suatu langkah kebijakan atau policy yang merupakan bagian dari politik hukum (penegakan hukum), politik hukum pidana, politik kriminal dan politik sosial. 18

Terkait dengan kejahatan terorisme maka proses pemidanaan terhadap pelaku untuk menjaga stabilitas keamanan. Untuk itu di berlakukannya syarat umum pembebasan bersyarat untuk di atur dalam pidana khusus. Niewenhuis, berpendapat bahwa pembentuk produk hukum perlu mempengaruhi hukum positif sehingga suatu penegakan hukum yang baik tidak akan ada tanpa adanya prinsip-prinsip keadilan yang di tuangkan dalam produk hukum. ${ }^{19}$

Melalui program deradikalisasi diharapkan sebagai upaya pencegahan agar tidak terjadi terorisme. Namun karena belum efektif sebagai suatu upaya, maka Perlu pembatasan hak narapidana dalam menolak program deradikalisasi yang di atur dalam Undang-Undang No. 5 Tahun 2018 Tentang Pemberantasan Tindak Pidana Terorisme. Hal ini dikarenakan pembatasan hak seseorang hanya boleh di lakukan oleh Undang-Undang pembatasanpembatasan yang tidak bertentangan dengan UUD 1945, khususnya Pasal 28J ayat (2) yang menyatakan, pembatasan dapat dilakukan dengan maksud semata-mata untuk menjamin

17 Handrawan, "Pemulihan Hak Politik Melalui Mekanisme Konstitusional”, Halu Oleo Law Review, Volume 2 Issue 1, Maret 2018 hlm. 410.

18 Herman, "Upaya Non Penal Dalam Penanggulangan Tindak Pidana Korupsi”, Halu Oleo Law Review, Volume 2 Issue 1, Januari 2018, hlm. 311.

19 Yohanes Sogar Simamora, Hukum Perjanjian Prinsip Hukum Kontrak Pengadaan Barang dan Jasa Oleh Pemerintah, Yogyakarta: Laksbang Pressindo, 2009, hlm. 36-37. 
pengakuan serta penghormatan atas hak dan kebebasan orang lain dan untuk memenuhi tuntutan yang adil sesuai dengan pertimbangan moral, nilai-nilai agama, keamanan, dan ketertiban umum dalam suatu masyarakat.

Menurut penulis, ratio legis pemenuhan hak bagi narapidana terorisme dalam memperoleh pembebasan bersyarat bahwa pidana bertujuan membalas kesalahan dan mengamankan masyarakat. Tindakan ini dimaksudkan mengamankan dan memelihara tujuan. Jadi pidana dan tindakan bertujuan mempersiapkan untuk mengembalikan terpidana ke dalam kehidupan bermasyarakat". 20Penjatuhan pidana bukan semata-mata sebagai upaya pembalasan dendam, namun yang paling penting ialah sebagai upaya pemberian bimbingan dan pengayoman. Pengayoman kepada masyarakat sekaligus kepada terpidana sendiri agar menjadi insaf dan dapat menjadi anggota masyarakat yang baik. Dalam literatur berbahasa Inggris kerap kali dikemukakan bahwa hak berdasarkan hukum (legal right) dibedakan dari hak yang timbul dari norma lain. Hak berdasarkan hukum biasanya diartikan sebagai hak yang diakui dan dilindungi oleh hukum. Dari hukum yang nyata timbul hak yang nyata. Sebaliknya dari hukum yang imajiner yaitu hukum alam, timbul hak yang bersifat imajiner.

Tujuan perlindungan hukum merupakan tercapainya keadilan. Fungsi hukum tidak hanya dalam upaya mewujudkan kepastian hukum saja, tetapi juga agar tercapainya jaminan dan keseimbangan yang sifatnya tidak sekedar adaptif dan fleksibel, akan tetapi berfungsi juga untuk menciptakan keseimbangan antara pelaku tindak pidana teroris dan, pemerintah dengan rakyat. Hukum sangat dibutuhkan untuk melindungi mereka yang lemah atau belum kuat untuk memperoleh keadilan sosial.

Menurut penulis bahwa perlu adanya kewajiban pelaku tindak pidana terorisme dalam UU No. 5 Tahun 2018 Tentang Pemberantasan Tindak Pidana Terorisme hal ini di maksud agar memberikan kepastian hukum dalam pelaksanaan program deradikalisasi tersebut program deradikalisasi di lakukan seyogyanya bukan sebagai upaya dalam pemberian bebas bersyarat melainkan sebagai upaya yang wajib kepada setiap orang yang terlibat dalam tindakan terorisme, dan memberikan batasan terhadap hak terorisme dalam penolakan mengikuti program deradikalisasi.

Secara umum, pemberian Pembebasan Bersyarat khususnya bagi narapidana terorisme, dapat dilaksanakan melalui sistem informasi pemasyarakatan. Sistem informasi pemasyarakatan merupakan sistem informasi pemasyarakatan yang terintegrasi antara Unit

20 Andi Hamzah, Sistem Pidana dan Pemidanaan Indonesia, Jakarta, Pradnya Paramita, 1993, hlm. 32. 
Pelaksana Teknis Pemasyarakatan, Kantor Wilayah, dengan Direktorat Jenderal Pemasyarakatan. ${ }^{21}$

Menurut penulis, selain program deradikalisasi jika merujuk pada Undang-Undang Nomor 12 Tahun 1995 tentang Pemasyarakatan, telah terdapat konsep rehabilitasi dan reintegrasi sosial dalam pembinaan di lembaga pemasyarakatan sebagai upaya penegakan hak asasi manusia dari setiap narapidana yang ada khususnya Narapidana Terorisme.

Rehabilitasi dilakukan melalui pembinaan narapidana terorisme meliputi fasilitas olahraga. Fasilitas pembinaan mental dilakukan melalui siraman rohani oleh petugas lembaga pemasyarakatan setiap 2-3 kali seminggu. Pembinaan non fisik juga berupa pelaksanaan hak dari narapidana yakni hak mengunjungi keluarga, cuti menjelang bebas dan cuti bersyarat.

\section{KESIMPULAN}

Berdasarkan hasil dan pembahasan, penulis dapat memberikan kesimpulan sebagai berikut:

1. Pembebasan Bersyarat Terhadap Narapidana Pelaku Tindak Pidana Terorisme Dalam Perspektif Hak-hak Narapidana bahwa Pembebasan bersyarat merupakan hak asasi manusia yang kemudian hak asasi tersebut dituangkan dalam produk hukum yang di atur dalam Undang-Undang No. 39 tahun 1999 tentang hak asasi manusia dimana dinyatakan bahwa salah satu Hak bagi narapidana teroris adalah memperoleh pembebasan bersyarat. Pemenuhan hak narapidana pelaku tindak pidana terorisme untuk memperoleh pembebasan bersyarat, sesuai dengan konsep keadilan restoratif atau restorative justice yang mengedepankan adanya pemulihan hak terhadap pelaku tindak pidana terorisme.

2. Ratio Legis Pemberian Bersyarat Bagi Narapidana Terorisme, didasarkan pada prinsip pemberian hak dan tanggung jawab pemerintah bahwa Pembebasan bersyarat tersebut dimaksudkan sebagai sisa pidana terakhir dalam rangka pengembalian terpidana dengan baik ke masyarakat. Terkait dengan kejahatan terorisme maka proses pemidanaan terhadap pelaku untuk menjaga stabilitas keamanan negara. Selain itu, Program deradikalisasi sebagai upaya pemerintah untuk mereduksi kegiatan radikal dan menetralisasi paham radikal bagi masyarakat yang terlibat tindak pidana terorisme program ini dilakukan sebagai upaya dalam pembebasan bersyarat bagi narapidana terorisme.

21 Pasal 94 Peraturan Menteri Hukum dan HAM No. 3 Tahun 2018. 


\section{Daftar Pustaka}

\section{Buku}

Abdussalam, HR., Sistem Peradilan Pidana, Jakarta: Restu Agung, 2007.

Alius, Suhardi, Pemahaman Membawa Bencana: Bunga Rampai Penanggulangan Terorisme, Jakarta: Gramedia Pustaka Utama, 2019.

Asmasasmita, Romli, Kapita Selekta Kejahatan Bisnis dan Hukum Pidana, Buku 2, Jakarta: Fikahati Aneska, 2013.

Asshiddiqie, Jimly, Konstitusi dan Hak Asasi Manusia, Jakarta: Konstitusi Press, 2005.

Atmasasmita, Romli, Analisis dan Evaluasi Peraturan Perundang-undangan tentang Pemberantasan Tindak Pidana Terorisme (Undang-Undang Nomor 15 tahun 2003), Jakarta: Badan Pembinaan Hukum Nasional Kementerian Hukum dan Hak Asasi Manusia, 2012.

Djisman, Samosir, Fungsi Pidana Penjara Dalam Sistem Pemidanaan di Indonesia, Bandung: Bina Cipta, 2001.

Hamzah, Andi, Sistem Pidana dan Pemidanaan Indonesia, Jakarta, Pradnya Paramita, 1993.

Marzuki, Peter Mahmud, Penelitian Hukum, Jakarta: Kencana Group, 2005.

Pandjaitan, Petrus Irwan, Wiwik Sri Widiarty, Pembaharuan pemikiran DR. Sahardjo Mengenai Pemasyarakatan Narapidana, Jakarta: Indhill Co, 2008.

Priyatno, Dwidja, Sistem Pelaksanaan Pidana Penjara di Indonesia, Bandung: Refika Aditama, 2006.

Setiardja, A. Gunawan, Hak-Hak Asasi Manusia Berdasarkan Ideologi Pancasila. Yogyakarta, Kanisius, 1993.

Simamora, Yohanes Sogar, Hukum Perjanjian Prinsip Hukum Kontrak Pengadaan Barang dan Jasa Oleh Pemerintah, Yogyakarta: Laksbang Pressindo, 2009.

Zuhri, Saefudin, Deradikalisasi Terorisme, Jakarta: Daulatpress, 2017.

\section{Jurnal}

Handrawan, "Pemulihan Hak Politik Melalui Mekanisme Konstitusional”, Halu Oleo Law Review, Volume 2 Issue 1, Maret 2018.

Haris, Oheo K., "Telaah Yuridis Penerapan Sanksi Pidana Di Bawah Minimum Khusus Pada Perkara Pidana Khusus", Jurnal Ius Kostituendum, Volume 2 Issue 2, Oktober 2017. Herman, “Upaya Non Penal Dalam Penanggulangan Tindak Pidana Korupsi”, Halu Oleo Law Review, Volume 2 Issue 1, Januari 2018. 


\section{Peraturan Perundang-undangan}

Undang-Undang Dasar Negara Republik Indonesia 1945

Undang-Undang Nomor 1 Tahun 1946 Tentang Kitab Undang-Undang Hukum Pidana (KUHP).

Undang-Undang Nomor 8 Tahun 1981 Tentang Kitab Undang-Undang Hukum Acara Pidana (KUHAP).

Undang-Undang Nomor 39 Tahun 1999 tentang Hak Asasi Manusia.

Undang-Undang Nomor 5 Tahun 2018 tentang Perubahan atas Undang-Undang Nomor 15

Tahun 2003 tentang Pemberantasan Tindak Pidana Terorisme

Peraturan Pemerintah Nomor 99 Tahun 2012 tentang Syarat dan Tata cara Pemberian Hak Narapidana.

Peraturan Menteri Hukum dan Hak Asasi Manusia Nomor M.HH-OT.02.02 tahun 2009 Tentang Cetak Biru Pembaharuan Pelaksanaan Sistem Pemasyarakatan.

Peraturan Menteri Hukum dan Hak Asasi Manusia Republik Indonesia Nomor 03 Tahun 2018 Tentang Syarat Dan Tata Cara Pemberian Remisi, Asimilasi, Cuti Mengunjungi Keluarga, Pembebasan Bersyarat, Cuti Menjelang Bebas, Dan Cuti Bersyarat.

Peraturan Menteri Hukum dan Hak Asasi Manusia Republik Indonesia No. 35 Tahun 2018 Tentang Revitalisasi Penyelenggaraan Pemasyarakatan.

Peraturan Menteri Hukum dan Hak Asasi Manusia Republik Indonesia No. 12 Tahun 2013 Tentang Asesment Resiko dan Asesment Kebutuhan Bagi Narapidana dan Klien Pemasyarakatan.

\section{Situs internet}

Affan, Heyder, "Mengapa 400 eks napi terorisme tidak ikut program deradikalisasi?”, BBC Indonesia, https://www.bbc.com/indonesia/indonesia-39177219, diakses pada tanggal 20 Agustus 2019. 